Pecvnia, 8 (2009), pp. 149-181

\title{
Pretextos y contextos olvidados: Arte, ciencia y técnica en algunos tratados contables de la Inglaterra Tudor
}

Recibido: Diciembre 2008

Aceptado: Septiembre 2009

\author{
J. Lanero Fernández \\ juan.lanero@unileon.es \\ Universidad de León \\ Fac. de Ciencias Económicas y Empresariales \\ Campus de Vegazana, $\mathrm{s} / \mathrm{n}$ \\ 24071 León (España)
}

El presente estudio pretende ver, desde una perspectiva amplia, los dos tratados de James Peele $(1553,1569)$. The pathe waye (1569), en su conjunto, se aparta de forma considerable de los tratados publicados con anterioridad; y por lo que se refiere a su primer libro (1553), dispone de suficientes rasgos diferenciadores para que en el todo y en las partes sea una pieza bien distinta de tratados anteriores. Algunos detalles de The maner and fourme provienen directamente de Pacioli o a través del primer tratado inglés de partida doble, obra de Hugh Oldcastle (1543), o de Ympyn. La influencia de éste, por su tratado holandés/francés (1543) y la traducción inglesa (1547), se aprecia
The present paper tries to have a look, from a broad perspective, at James Peele's two treatises $(1553,1569)$. The pathe waye (1569), as a whole, drifts away considerably from the treatises previously published; and as far as the first book is concerned (1553), it has enough differentiating features to be, as a whole and in detail, a total different production from previous treatises too. Nevertheless, some details of The maner and fourme come either directly from Pacioli's or through the first English treatise by double entry, Hugh Oldcastle's (1543) or Ympyn's. The latter's influence through the Dutch/French version (1543) and its English translation (1547)

Ponencia presentada en la $V$ Jornada de História da Contabilidade organizada por la Associação Portuguesa de Técnicos de Contabilidade (APOTEC), Lisboa, Noviembre 2008. 
en The pathe waye en el cierre del Libro Mayor y en la forma que ambos tienen de tratar las operaciones de trueque. Es un hecho que Manzoni (1540) está presente en The maner and fourme en lo tocante a la numeración de las partidas en el Diario y a su referencia en el texto. Por lo que se refiere a la organización de los libros de cuentas, también existen resonancias de Weddington.

La excelencia es la cualidad que destaca en los dos tratado, en particular en The pathe waye. Peele supo recoger en sus libros las tendencias más innovadoras de la partida doble provenientes de los autores que le precedieron. Está demostrado que Mellis manejó, aunque no siempre de forma apropiada, los tratados de Peele para su reedición de Oldcastle (1588). Y se puede decir lo mismo de John Carpenter (1632). Pele comprendió los verdaderos principios de la partida doble; pero sus excelentes tratados se quedaron injustamente olvidados en la penumbra de los pretextos, la competencia de los contextos y casi ningún paratexto que los valorara en su justiprecio que fue, y sigue siendo, elevado.

Palabras clave: Teneduría de libros; partidas; trueque. can be seen either in the closure of the Ledger in The pathe waye or in the way both deal with barter transactions. It is a fact that Manzoni's (1540) is present in The maner and fourme as far as the numbering of the entries in the journal and its reference in the text is concerned. And the organization of the account books there are echoes from Weddington.

Excellence is the outstanding quality in both treatises, particularly in The pathe waye. Peele was wise enough to gather in his books the innovating double-entry tendencies coming from the preceding authors. It is evident that Mellis handled, though not always in the appropriate way, Peele's treatises for his Oldcastle's reedition (1588); and the same thing applies to John Carpenter (1632). Peele properly understood the true principles informing the double entry system. Unfortunately, his two superb treatises were unfairly forgotten in the darkness of the pretexts, the competence of the contexts and barely any paratext assessing their value which was, and still is, high.

Key words: Bookkeeping, entries, barter.

La historiografía contable, con frecuencia y en exceso, se centra y concentra en tratados notables sin considerar qué textos los precedieron y sucedieron. Ninguna obra que sale de la mente humana es un borbotón espontáneo. Guarda siempre relación con el pasado, refleja el presente que la rodea, marcha hacia el futuro tamizada por el paso del tiempo y es reinterpretada por las circunstancias del momento.

Inglaterra, durante los reinados de la dinastía Tudor, experimentó cambios drásticos y en ocasiones traumáticos. La Reforma eclesiástica promovida por Enrique VIII no fue un hecho aislado; el breve reinado de su hijo, Eduardo $\mathrm{VI}$, quiso poner fin a los enfrentamientos entre católicos y protestantes, aunque de poco sirvieron sus esfuerzos; el no menos breve reinado de su hermana María pretendió devolver a Inglaterra a la senda de Roma. Sus años fueron preludio de la coronación de Isabel I. Con ella Inglaterra se encaminó hacia una época de prosperidad política, 
económica y comercial, si bien siempre presidida por la enigmática monarca que no vaciló en ordenar la decapitación de su prima María, reina de Escocia, ni en nombrar al hijo de ésta heredero del trono unificado de Inglaterra y Escocia. Durante el largo reinado isabelino -cuarenta y cinco años-, se produce la eclosión del embrión que daría paso al Imperio Británico; igualmente encontramos los orígenes del estado moderno. Los mercaderes hicieron su pertinente contribución a este despegue con sus compañías gremiales. Un paño de seda lo envolvió todo, o casi todo: los tratados contables que de forma pausada y constante fueron introduciendo un nuevo sistema de llevar los libros de cuentas: la partida doble.

El presente estudio pretende ver, desde una perspectiva amplia, los dos tratados de James Peele $(1553,1569)$. Es oportuno observar de qué modo el autor inglés fue heredero de los tratados contables anteriores y hasta qué punto se convirtió en un nuevo punto de partida para la contabilidad inglesa.

Comprobar las influencias que confluyen en los tratados de Peele no es tarea fácil a pesar de los valiosos estudios que, en la década de 1920, publicó el profesor holandés P. Kats y en la bella edición facsimilar que, en 1979 editaron, con dos artículos densos y bien documentados, los historiadores contables Kojima y Yamey ${ }^{1}$ y que allanan el camino de nuestro trabajo. Peele pudo estar influido por profesionales de la teneduría de libros o por maestros de escuela que enseñaban la materia. Esas influencias, pues, son difíciles de valorar. No obstante, también existen casos que ilustran lo complicado que puede ser sistematizar las influencias que Peele recibió. Así, en su segundo tratado, The pathe waye $(1569)^{2}$, Peele, al abordar el sistema contable que debe usarse en un establecimiento minorista, dice:

Cfr. P. Kats, "De invloed der Nederlanders de 16e en 17e eeuw op de Engelsche literatur van het boekhouden", Maandblad voor het boekhouden, 32, 1925; "Double-Entry Book-keeping in England before Hugh Oldcastle", The Accountant, 64, 1926, pp. 91-98; "Hugh Oldcastle and John Mellis-l", The Accountant, 64, 1926, pp. 483-487; "Hugh Oldcastle and John MellisII. The 'Briefe Instruction' by John Mellis", The Accountant, 64, 1926, pp. 641-648; "James Peele's 'Maner and Fourme,"' The Accountant, 82, 1930, pp. 41-44; 88-91; 119-122, Véase también James Peele, The pathe waye to perfectnes, in th'accomptes of debitour and creditour, Eds. Osamu Kojima, B.S. Yamey, 2 vols., Kyoto: Daigakudo Books, 1979.

James Peele, The pathe waye to perfectnes in thaccomptes of Debitour, and Creditour: in manner of a Dialogue, very pleasaunte and proffitable for Marchauntes and all oth' that minde to frequente the same: once agayne set forthe, and very much enlarged. By lames Peele Cittizen ans Salter of London, Clercke of Christes Hospitall, practizer and teacher of the same. Imprinted at London, in Paules Churchyarde. By Thomas Purfoote, dwellinge at the signe of the Lucrece. 16 August. Wisdome and Science Preuent Indigence. Practise procuereth perfection: la. Peele. 1566 (sic); 1569. 
There is to be preprared for a retayle accompte, in principall bookes, to saye, a Journall and a Leager thereunto. And a shoppe booke for sale of all thinges solde for readye monie, all which bookes must euerye of them haue his style, with the daye and yeare, where in the be begonne. Then shall the Master him selfe or suche one as maye some good to him begin with the Leager referuinge the first leafe for his stocke, and in folio. 2 . on the debitour syde enter the readie monie... ${ }^{3}$.

Kats utiliza la referencia al shoppe booke (libro de tienda) como ejemplo de la influencia ejercida por el tratadista holandés Ympyn en Peele, aunque señala que la forma de llevar las cuentas de ventas al por menor difiere de uno a otro. Kats destaca que Ympyn fue el primero en la literatura contable que mencionó el uso de un libro de cuentas para el establecimiento minorista. No obstante, en la práctica, este tipo de libro para operaciones al detall ya se venía utilizando, como puede comprobarse en el Libro Mayor de Smythe (1438-1550) ${ }^{4}$. Es verosímil aceptar que Peele pudo sentirse influido por la práctica habitual y por el tratado de Ympyn. Todo parece indicar que la primera presenta más credibilidad, dado que en la versión inglesa del tratado de Ympyn, $A$ notable and very excellente woorke... (1547) el término que se utiliza es retaile boke y no shoppe booke; además el enfoque que Peele da a los negocios minoristas es distinto del de $\mathrm{Ympyn}^{5}$.

Por otra parte, desconocemos qué lenguas dominaba Peele; o si pudo recibir ayuda de algún intermediario que pusiera a su disposición algún tratado publicado en una lengua que no fuera la inglesa. Además, la temática pudo tener cierto efecto constrictivo en la disposición de los puntos a tratar; de ahí que algunos tratados contables de la época tengan muchos aspectos en común. Pese a todo lo que acabamos de señalar, The pathe waye de Peele, en su conjunto, se aparta de forma

3 La itálica es nuestra.

4 Cfr. P. Kats, "De invloed der Nederlanders de $16 \mathrm{e}$ en $17 \mathrm{e}$ eeuw op de Engelsche literatur van het boekhouden", ed. cit. Véase igualmente Jean Vanes, ed. The Ledger of John Smythe, 1530-1550, from the Transcript Made by John Angus, London: Her Majesty's Stationery Office, 1974, p. 118, y J. J. Lanero, "Mercaderes ingleses de la época Tudor: Los libros de cuentas de Sir Thomas Gresham y John Smythe", Nuevos estudios sobre la historia de la contabilidad: orare et rationem reddere, Esteban Hernández Esteve y Begoña Prieto Moreno, coords., Diputación Provincial de Burgos, 2008, pp. 307-330.

5 Jan Ympyn Christoffels, $A$ notable and very excellente woorke, expressyng and declaryng the maner and forme how to kepe a boke of acco $(m)$ ptes or reconynges, verie expedient and necessary to all Marchantes, Receiuers, Auditors, Notaries and all other. Translated with greate diligence out of the Italian toung into Dutche and out of Dutche, into French, and now out of Frenche into Englishe. London: Richard Grafton, 1547. 
considerable de los tratados publicados con anterioridad; y por lo que se refiere a su primer libro, impreso en 1553, dispone de suficientes rasgos diferenciadores para que en el todo y en las partes sea una pieza bien diferenciada de tratados anteriores.

Lo antedicho no excluye que algunos detalles de The maner and fourme provengan directamente de Pacioli o a través del primer tratado inglés de partida doble, obra de Hugh Oldcastle (1543), o de la versión inglesa de Ympyn (1547). De este modo, el primer capítulo de Peele, en el que se dan consejos al contable de lo que es estrictamente necesario, guarda cierta similitud con el primero de Pacioli, aunque el fraile italiano resulta ser más prolijo en lo que un mercader precisa. La preocupación por la conservación de documentos y de la correspondencia, que poco tienen que ver con la teneduría de libros, está presente en Pacioli y en Peele. El capítulo XI de Peele (de forma errónea figuran dos capítulos numerados con esta cifra; el primero corresponde al $X$ ) dice que el inventario se debe cerrar en el día, "which in no wise must be deuided into mo[re] daies then [than] one", se asemeja al II de Pacioli, "e tutto detto Inventario si deve tenere in un medesimo giorno perchè altramente darebbe travaglio nel maneggio futuro"6. Pero Peele, lo mismo que Mellis (1588), no esgrime ninguna razón para este requisito a diferencia de Pacioli que afirma que, de no hacerse se entorpecerá el negocio. Tenemos otro caso referente a las cuentas del negocio minorista del mercader. Peele dice en el capítulo IV que el empleado que regenta la tienda no debe ser considerado deudor de la mercancía enviada al establecimiento:

If your shoppe wherin you do retaile, be kept by your prentices, for any wares therinto deliuered, nor yet to a Journeyman, without he consent \& agree therunto, and be willing to make answere for your goodes so deliuered ${ }^{7}$.

\footnotetext{
James Peele, The maner and fourme how to kepe a perfecte reconyng, after the order of the moste worthie and notable accompte, of Debitour and Creditour set foorthe in certain tables, with a declaration therunto belongyng, verie easie to be learned and also profitable, not only unto suche, that trade in the facte of Marchaundise, but also unto any other estate, that will learne the same. 1553. Imprinted at London, by Richard Grafton, printer to the Kinges Maiestie. Cum priuilegio ad imprimemdum solum. Para las citas de Pacioli utilizamos Fra Luca Paciolo, Tractatus de Computis et Scripturis. Trattato de' Computi e delle Scritture, con Prefazione e Note, Edito per cura del Prof. Vincenzo Gitti, Torino: Tip. e Lit. Camilla e Bertolero, 1878, p. 37.
}

7 La itálica es nuestra. 
Este concepto está recogido en el capítulo XXIII de los tratados de Pacioli y Mellis. Las coincidencias vistas hasta ahora podrían llegar a considerarse una mera casualidad con independencia de que estén incorporadas al tratado de Peele.

En otros casos, en los que parecen existir resonancias de Pacioli en Peele, se puede contemplar la originalidad de éste. Así sucede con el primer capítulo de Pacioli en el que dice que lo primero y más importante para un mercader es el dinero o sustancia y que muchos acaudalados mercaderes italianos comenzaron sus negocios sin más activos que los créditos recibidos:

... la pecunia numerata e ogni altra facoltà sostanziale, iuxta illud phy. unum aliquid necessarium est substantia, senza il cui suffragio mal si può il maneggio trafficante esercitare; avvenga che molti, già nudi, con buona fede cominciando, di gran faccende abbino fatto, e mediante lo credito fedelmente servato in magne ricchezze sieno pervenuti, chè assai per Italia sieno discorrendo n'abbiamo conosciuti $^{8}$

También Peele, en el capítulo II de The maner and fourme, alude al mercader que inicia su negocio sin activos: "... he that hath no goodes (but suche at his beginnyng, he taketh on credite) nedeth no Inuentorie, but maie begin with his Jornall". Weddington (1567) también lo menciona; las palabras que utiliza indican que pudo tener las de Peele como modelo.

Un segundo ejemplo se refiere al hecho de que, en la práctica más temprana de la partida doble, toda la información recogida en el Libro Diario también se encuentra en el correspondiente Mayor y que todas las partidas de ambos libros están entrelazadas. Pacioli, en su capítulo XV, señala que si un mercader perdiera su Libro Mayor, lo podría reconstruir desde el Diario:

E nota che avendo tu perduto il tuo Quaderno per alcun caso di ruberia o incendio di fuoco e naufragio, ecc., e avenddo tu l'uno degli altri due libri, cioè Memoriale ovvero Giornale, con esso ptrai sempre rifare un altro Quaderno con le medesime partite a di per di e ponerle al numero delle medesime che in quello perso si retrovavano; massime avendo tu il Giornale dove quando ne levasti le partite e ponesti al Libro, tu in margine vi

8 Fra Luca Paciolo, opus cit., p. 34. 
ponesti i due numeri dei debitori e creditori l'uno sovra l'altro, che chiamavano le carte del Quaderno dov'erano situati; ed appunto a tante carte li potrai fare ritornare con tuo ingeno. $E$ questo basti quanto a una partita posta?

Peele, a su vez, en The maner and fourme considera otra implicación de la correspondencia entre Diario y Mayor. Al final del capítulo VIII aconseja que, en caso de desacuerdo entre el mercader y su contable o factor, aquél deberá poner el Libro Mayor bajo su custodia:

... when it shall chaunce (as many times it dooeth any variaunce, betwene the owner of the accompt, and the said accompt keper: by reason wherof, the owner foorth with, will receiue into his custodie that his accompt, then is to bee deliuered unto hym, but the Quaterne onely, and the Journall hauyng all thynges agreable therunto, to remain in the others custody whereby there can be no maner of subtletie wrought, of neither part, by any alteracion: for these twoo bookes ought alwaies to agree, as indentures.

El segundo tratado de Peele carece de reminiscencias paciolianas. Lo más cercano que tiene al texto de Pacioli se encuentra al final del diálogo entre el mercader y el maestro. Éste señala: "... accordinge to the prouerbe whear order is not kepte ther must nedes be confucion". Pacioli expresa en latín el mismo sentir en el primer capítulo de su tratado: "luxta comune dictum, ubi non est ordo ibi est confusio". Oldcastle, a través de la reedición de Mellis de 1588, viene a decir lo mismo:

... the businesse misordered out of due place, myght cause great errour and confusion, according to a common saying: Vbi non est ordo, ibi est confusio. Which is to meane: there must needes follow much confusion, where is no order ${ }^{10}$.

Otro caso de préstamo, o coincidencia, se encuentra en la clasificación que hace Peele referente a qué cosas se deben registrar en el Borrador y no deben aparecer en el Diario y, por extensión, tampoco en

$9 \quad$ Ibid., pp. 68-69.

10 John Mellis, A briefe instruction and maner hovv to keepe bookes of Accompts after the order of Debitor and Creditor, as well as for proper Accompts partible \& c. By the three bookes named the Memoriall lournall \& Leager, and of other necessaries appertaining to a good and diligent marchant. The which of all other reckoninges is most lawdable: for this treatise well and sufficiently knowen, all other wayes and maners may be the easier \& sooner discerned, learned and knowen. Newly augmented and set forth by John Mellis Scholemaister, 1588. Imprinted at London by lohn Windet, dwelling at the signe of the white Beare, nigh Baynards Castle, 1588. 
el Mayor. Ese sería el caso del dinero o de las cosas que se toman prestadas, o se prestan, por unos días:

... some of the percelles in the memoriall shall neuer be borne into the Journall, that is to saye, money and wares borowed or lent for a daye $\mathrm{ij}$ or $\mathrm{ij}$, and beinge receaued or deliuered agayne, is there uppon to be discharged presently without anye farther trauaile, sauinge to crosse the percell and mencion the tyme of receipt at deliuery thereof in the margent.

En efecto, los datos sólo se anotan en el Borrador y cuando se devuelve el préstamo, se tacha la anotación.

Pacioli, a su vez, en un párrafo al final del capítulo sin numerar de su tratado, titulado "Casi che accade mettere alle ricordanze del mercante", menciona los préstamos de joyas o vajilla de oro o plata en favor de un amigo por un tiempo entre ocho y quince días. Teniendo en cuenta que los va a devolver, el asunto no debe anotarse en el Libro Mayor, sino únicamente en un diario que el fraile italiano denomina ricordanze:

Prestando qualche gioia, o vasellamenti d'argento o d'oro, a qualche tuo amico per otto quindici giorni, di queste tali cose non si mettono al Libro, ma se ne fa ricordo alle ricordanze, perchè fra pochi giorni l'hai a riavere ${ }^{11}$.

Y lo mismo habrá de hacerse cuando se reciban préstamos de amigos. Pues bien, cabe preguntarnos: ¿en quién o en qué se inspiró Peele, en el tratado pacioliano o en la práctica diaria? Oldcastle (1543), a través de la edición de Mellis (1588), en el capítulo XXIV, sigue a Pacioli, aunque no se limita a los préstamos a corto plazo:

... you may put in remembrance any vessell, plate, implement of your shoppe, or any other thing that you sende to your friends, with diuers other matters, that you woulde keepe in remembrance, as the birth of children, the death of friends, or any other notable thing.

Ympyn (1547) también alude al tema en su capítulo XXIII, aunque no hay ninguna indicación de que se esté refiriendo a préstamos concedidos a amigos por un breve espacio de tiempo:

... suche thinges as is not mete to be written in the Jornall, nor in the greate boke (...). there is requisite

11 Fra Luca Paciolo, opus cit., p. 136. 
also to be kept a Memoriall boke, when ye shall write what thynges ye lend out as hattes, bogettes, males, botes, clokes, woodknives or any other thyng...

Figura 1: Girolamo Castiglione Cardano, Practica Arithmetice, \& Mensurandi singularis (1539)

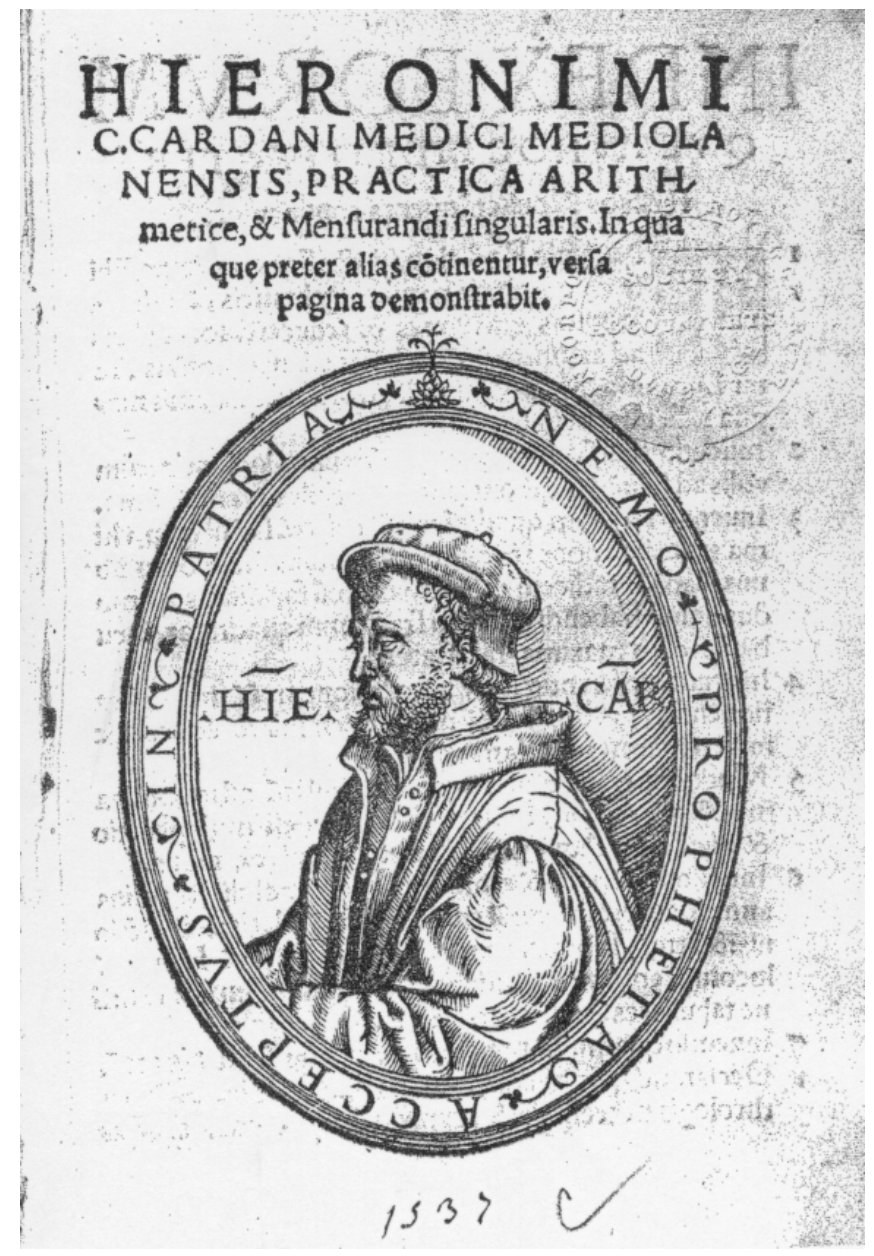

El tema de los préstamos a corto plazo es uno de los doce aspectos, en concreto el once, de que consta la exposición latina de teneduría de libros -de cuatro páginas de extensión-, recogida en el tratado de Cardano, Practica Arithmtice \& Mesurandi singularis (1539), capítulo LX, titulado en el índice "De ratione librorum mercature" y en el texto "De ratione librorum tractandorum" (véase Figura 1): 
11. Reru(m) viliu(m) \& mutuor(um) sub breui tempore dator(um) aut acceptor(um) nulla fiet qua(n)qua(m) magni sint $\mathrm{pr}(\mathrm{oe})$ tii memoria in libris sed in paruo quoda $(\mathrm{m})$ rer(um) quottidianar(um) libello ${ }^{12}$.

III

Es un hecho que el Qvaderno doppio col suo giornale (1540) de Domenico Manzoni está presente en The maner and fourme de Peele en lo tocante a la numeración de las partidas en el Diario y a su referencia en el texto ${ }^{13}$.

El Profesor Kats señala otras similitudes entre Manzoni y Peele, lo que, a su entender, demuestra que el tratado de Manzoni era conocido en Londres:

Booth size the approach of the coming year as an opportunity of dedicating their work to their patrons and are prompted by the same lofty motives in the compilation thereof; the Italian, in order to benefit his fellow men, according to the talents that God has given him, the English author will, according to the small Talent that God has given him, apply his study and whole endeavour to profit a common wealth, and if he is compelled to say with Peter: "Gold and silver have I none," the other confesses: "Riches I do not possess." Manzoni had lived laborious days and sleepless nights in compiling his treatise, while Peele assures his patron and the reader that the writing of his book had been very painful to him. The Italian can only write in the simple language (Venetian vernacular) that he had learned from his mother; polished composition must not be expected of him, and the English author does not write with subtle terms of other languages but rather uses such plain and familiar speech as, in our language he can devise, and both endeavour to write so lucidly that any reader would understand the art at once and be able to apply it. Like Manzoni, Peele numbers and annotates the entries in the

12 Girolamo Castiglione Cardano, Practica Arithmetice, \& Mensurandi singularis. In qua que preter alias co(n)tinentur, versa pagina demonstrabit, Mediolani [Milán]: Annoa virgineo partu. M.D.XXXIX. Antonius Canellioneus Mediolani imprimebat impensis Bernardini Calusa.

13 Domenico Manzoni, Quaderno doppio col suo giornale, novamente composto, \& diligentissimamente ordinato, sicondo il costume di Venetia. Opera a ogni persona vtilissima, \& molto necessaria. Di Dominico Manzoni Opitergiense. Cvm gratia et privilegio del Illustrissimo Senato di Venetia, per Anni diece. MDXXXX. 
journal, though with a slight difference in the arrangement; both use P(er) and A (in English By and to) in the text of their ledgers, which both call Quaterno or Quaterne. In compiling the journal entries Peele tells his readers: "Your general rule is ... to make the thing or things received debtor to the thing or things delivered, or the receiver debtor to the deliverer," which Manzoni puts this way: "He who sells for ready money always makes his cash debtor, and he who buys makes his cash creditor, and if the sale is on credit, then the seller makes the buyer debtor, and he who buys makes the seller creditor." Both speak of the memorial book but omit to exemplify it. Manzoni uses the letter R(to), i. e. "Resto" to denote balances transferred to or from another folio in the same or a new ledger; Peele teaches the use of the letter R for the same purpose, and if the Italian has an accounting year covering 12 months (I/3-28/2), Peele's "Maner and Fourme," too, covers twelve months, i.e. from the 25th to the 25 May following. Manzoni precedes his journal by a "Tavola" in which 300 entries are arranged in sections or chapters. Similarly, Peele arranges his entries in a methodical way and number them so that they may easily be traced in the journal ${ }^{14}$.

\section{IV}

La influencia de Ympyn, por su tratado holandés/francés (1543) y la traducción inglesa (1547), se aprecia en The pathe waye en el cierre del Libro Mayor y en la forma que ambos tienen de tratar las operaciones de trueque.

Ympyn se ocupa, de forma breve, del procedimiento de cierre en su texto. Sin embargo la brevedad de la exposición está compensada, y con creces, en el modelo de libros de cuentas que añade. El tratado de Ympyn es el primero de la literatura contable que incorpora una cuenta de balance como cuenta (la última) en el Libro Mayor saldado y cerrado. Igualmente es pionero en presentar con detalle las partidas de apertura en el nuevo Libro Mayor, con lo que el lector, en la práctica, no tendría dificultad en abrir un nuevo Libro Mayor con la información proveniente de su predecesor. Peele, en sus dos tratados, presenta la apertura de un nuevo Libro Mayor con sus partidas iniciales (si bien en The maner and

14 P. Kats, "James Peele's 'Manner and Fourme,"' ed. cit., pp. 41-42. 
fourme no está tan claro por la inclusión, que parece ser un añadido de última hora, de partidas referentes a operaciones de sociedades). No obstante, Peele no siguió el ejemplo de Ympyn en otros aspectos recogidos en The maner and fourme. En su cuenta de balance -ballaunce of accompt-, en el antiguo Libro Mayor, los saldos de la cuenta de capital -stocke-, y de la de pérdidas y ganancias se muestran de forma independiente, mientras que en el modelo de Ympyn el saldo de cierre de esta última se transfiere a la cuenta de capital, con lo que el saldo de cierre se refleja en la cuenta de balance. Es más, a diferencia de Ympyn, Peele tiene una especie de cuenta de balance de apertura en el nuevo Libro Mayor. En esta cuenta -Remain of balaunce in the last yeres accompte-, los saldos individuales de la cuenta de activo se muestran en el Haber y los saldos de la cuenta de acreedores en el Debe. Las partidas de compensación para esa cuenta restante (remain) se muestran en su debida forma, en el Debe o Haber de las nuevas cuentas del nuevo Libro Mayor. La cuenta restante (remain) se salda con la siguiente partida: "this reste taken on Creditor side, is the owners his nete substaunce, beyng borne to ballance in folio...". Pero no se indica ningún folio ni ninguna cuenta de capital en el recién abierto Libro Mayor. Si en este paso Peele hubiera realizado un saldo de comprobación de post-inventario, como el que menciona en el segundo diálogo de su tratado de 1569, habría comprobado que en el nuevo Libro Mayor no se cumple la máxima de que todo deudor tiene su acreedor y todo acreedor su deudor.

El propósito de Peele no está claro. Es posible que pretendiera que la cuenta de balance en el nuevo Libro Mayor fuera una cuenta de balance de apertura en la que las partidas de la cuenta de balance de cierre del Libro Mayor precedente se repetirían pero de forma inversa. Si Peele hubiera mostrado el saldo de apertura en la nueva cuenta de capital, no habría duda de sus intenciones. Si lo hubiera hecho, la inversión de la cuenta de balance de apertura habría sido el primer ejemplo de la literatura contable sobre este procedimiento que, por otra parte, ya lo utilizaban algunos mercaderes en sus cuentas ${ }^{15}$.

Entre 1553 y 1569 se publicaron tres libros en los que la constitución de una cuenta de balance invertida se incorpora de modo apropiado al proceso de saldo y cierre. El primer ejemplo lo encontramos

15 Ibid., p. 42. 
en Specchio Lvcidissimo (1558) de Aluise Casanoua ${ }^{16}$, aunque el autor no explica el procedimiento. John Weddington, a su vez, en $A$ breffe instruction how to kepe, marchantes bokes of accomptes (1567) describe, explica y da ejemplos de la cuenta de balance de apertura. Según Weddington, lo que hay que hacer es:

... fyrst make the Debitor perte of the ballans Creditor at the beginninge of your newe great Boke, to saie apon the seconde leaff in all thingis, like as it standethe in your olde great Boke, and the Creditor perte of the same ballance apon the Debitor side or fyrst leaff of your saide newe Boke, and by this manner you shall in Debitor and Creditor lincke, the one great Boke, withe the other, And all this beinge don, make other newe, accomptis in your new great Boke, for the same rest is, to saie for the Creditor side of the ballans make Debitors alonge in your newe great Boke, and for the Debitor side of the ballans, make Creditors alonge in your saide newe great Boke, and so you shall finde all the net restis of the saide accomptis to stande in like order, as in your olde great Boke, wherin you maie write all your businis untill it be full also, and then do withe that as you haue don withe your other olde Boke, unto the wiche this maye suffice -as more plainly aperethe at thende of this Boke in fo. $43 .{ }^{17}$.

Pierre Savonne, en su tratado Instrvction et maniere de tenir livres de raison ov de comptes par parties dovbles (1567) también describe la inversión de la cuenta de balance de apertura. Argumenta que es necesaria por razones técnicas de la teneduría de libros y también porque, con esta cuenta al inicio del nuevo Libro Mayor, no hace falta consultar el antiguo ${ }^{18}$.

16 Aluise Casanoua, Specchio Lvcidissimo, nel quale si uedeno essere diffinito tutti i modi, \& ordini de scrittura, che si deue menare nelli negotiamenti della Mercantia, Cambii, Recambii, con li loro corrispondente, disgarbugliando, \& illuminando l'intelletto a negotianti. Opera non piv veduta, composta per Aluise Casanoua, Cittadin Venetiano, Anno Domini. M.D.LVIII. Con gratia et Privilegio dell'Illustrissimo Senato di Venetia per anni diece.

17 John Weddington, A breffe instruction, and manner howe to kepe, marchantes bokes of accomptes. After the order of Debitor and Creditor, as well for proper accomptes, partable, factory, and other, \& c. Verry nedefull to be knowen, and vsid of all men, in the feattis of marchandize. Novve of late nevvly, set forthe, and practisyd, By lohan Weddington Cyttizen of London. M.D.LXVII. The trewthe sekethe no corners. Prenttyd in Andvvarpe by Petter van Keerberghen dvvellinge by ovvre lady Charche at the signe of the golden Sonne. Cvm Gratia et Privilegio.

18 Pierre Savonne, Instrvction et maniere de tenir livres de raison ov de comptes par parties dovbles: Auec le moyen de dresser Carnet pour le virement \& rencontre des parties, qui se font aux foires es payements de Lyon, \& autres lieux: Livre necessaire a touvs marchans \& autres personnes, qui s'entremectent d'aucunes affaires, ou negoces affectées a quelques conference ou rendition de comptes. Par Pierre Savonne, dict Talon, natif d'Auignon, Conté de Benisse A Paris. Au Compas d'Or, Rue Sainct lacques. M.D.LXVII. Avec privilege dv Roy. 
En el segundo libro de Peele se aprecian influencias de Weddington, pero no se incorporó esta innovación, con lo que su procedimiento para el cierre del Libro Mayor es semejante al de Ympyn.

En The maner and fourme Peele demuestra que conoce el ejemplo de Ympyn. Así, en el capítulo VIII señala:

There is other waies to make your Ballaunce, but all commeth to one effect, as to bryng your gooddes remainyng therunto, in one totall, bearing the particulers into a newe Quaterne booke, from eche seueral accompt: hauyng a double folio in your Balluunce, with other thynges, whiche herein to be spoken of, should litle profite, for that one onely ordre can but be taught in one booke ${ }^{19}$.

La práctica que Peele menciona sólo está presente en Ympyn y no en ningún otro tratado publicado antes de 1553; vuelve a aparecer en The pathe waye. Ympyn traspasa los saldos de cierre de las cuentas de mercaderías a una cuenta única que, a su vez, se traspasa a la cuenta de balance de cierre. Esta cuenta colectiva se vuelve a abrir en el nuevo Libro Mayor y se cierra inmediatamente, trasladando las cantidades individuales a las diversas cuentas de mercaderías que se han vuelto a abrir. Ni Ympyn ni Peele explican el objeto de la cuenta de mercaderías restantes -goodes remayninge-. Suponemos que formaba parte de una operación de limpieza para aligerar la cuenta de balance de algunas partidas. No está de más recordar que Wolfgang Schweicker, en su tratado Zwifach Buchhalten (1549) agrupa los saldos de deudores y acreedores en dos cuentas colectivas para la apertura de la cuenta de balance ${ }^{20}$.

En el segundo tratado de Peele (1569) hay dos columnas de referencia a cada lado de la cuenta de balance en el primer Libro Mayor (A), encabezadas por las letras A y B respectivamente. Conviene recordar respecto a los Libros Mayores de este tratado que el primero está marcado con la letra A y el segundo con la letra B. Este sistema también se observa en Casanova y Weddington. El primer Libro Mayor de The maner and fourme está marcado con el signo de la cruz y el segundo con la letra A, siguiendo el método de Pacioli, Manzoni e Ympyn. Pues bien, Peele en The pathe waye explica que en la columna $A$ se anota el número del folio

\footnotetext{
19 La itálica es nuestra.

20 Wolfgang Schweicker, Zwifach Buchhalten sampt seine(n) Giornal, des selben Beschlus, auch Rechnungzuthun \& c..... Nürnberg: Johan (n) Petreius, 1549.
} 
de la cuenta en el Libro Mayor A del que procede la partida; y en la columna $B$ se anota el número del folio de la cuenta abierta en el nuevo Libro Mayor marcado con la letra B. Peele dice que, de esta forma, "I have used as muche breuite as maye posible be put in practice, and have rejected the tediousnes that diuers use therin". Peele, además, contempla el uso de la denominada cuenta de mercaderías restantes -goodes remayninge-, que dispone de dos columnas de anotación, con lo que evita la necesidad de abrir una cuenta colectiva en el nuevo Libro Mayor. En este sentido, Peele mejoró el modelo que siguió.

\section{V}

Las operaciones de trueque se hallan descritas y explicadas en la inmensa mayoría de los primeros tratados contables de partida doble. Sin embargo, no está de más reparar en que la atención recibida se debe más a su utilidad como ejemplo de la dualidad de las operaciones que a la importancia de trueque en las relaciones comerciales de la época.

En la teneduría de libros del momento se solía tener una única partida simple en el Libro Diario para el intercambio directo de mercaderías contra mercaderías. En una cuenta de mercaderías se cargaba y en la otra se abonaba. Una variante que se daba era la de disponer de dos partidas simples en el Diario: el mercader con el que se hacía el negocio figuraba como acreedor en una y como deudor de lo mismo en la otra. Ambas alternativas ya están recogidas en el tratado de Manzoni. Cuando el valor de las mercaderías que se intercambiaban no coincidía, la diferencia se satisfacía en metálico, en pagarés de deuda o en una combinación de ambos sistemas.

Pacioli se ocupa del valor de las mercaderías o activos intercambiados que hay que anotar en las cuentas del Libro Mayor. El trueque es un aspecto importante para el fraile italiano. La aritmética de las operaciones de trueque es el tema de un Tractatus independiente de la Summa (Distinctio 9, Tractatus 3). En el Tractatus sobre teneduría de libros, capítulo IX, Pacioli cita nueve formas de comprar mercaderías: "Dei nove modi per i quali comunemente si costuma frai i mercanti comprare e delle mercanzie, quali al più delle volte di necessità a tempo si comprano". El tratamiento contable del trueque ocupa el capítulo XX. En él Pacioli explica que es preciso mostrar las mercaderías intercambiadas en su valor en metálico con el fin de que se pueda determinar si se 
producen pérdidas o ganancias con estas mercaderías. Si se anotan valores distintos en el Libro Mayor sería imposible determinar las consecuencias. El mismo consejo lo repite al final del Tractatus en el capítulo no numerado "Casi che appartiene a mettere al libro de' mercanti", en el que se aconseja al lector que valore la pimienta adquirida por trueque según su cálculo del valor monetario:"... stima quello che vale il piper, a tua discrezione, a denari contanti"21.

Ympyn se ocupa de este tema de forma más minuciosa. Su capítulo XVIII, que corresponde al XX de Pacioli que acabamos de ver, lleva el siguiente encabezamiento: "How to kepe accomptes of chaunges, called Barrato in Italian". Ympyn advierte de que "... in this thyng is speciall hede to bee taken, for in this maner of choppyng and chaungyng lieth greate hasard and daungier, and no little deceite and falsehed is wrought therin...". Distingue entre intercambios ordinarios, en los que la mercadería que se trate debe anotarse en ambos lados al precio del mercader, y el concepto de trueque que él tiene: ambas partes poseen un mismo objetivo: engañar al otro. Las partidas para este tipo de trueque engañoso se muestran en el modelo de Diario. Se precisan cuatro partidas simples. La cuenta de trueque (según terminología de Peele) se carga a la otra parte por la operación de las mercaderías recibidas, valoradas al precio de la transacción. En la siguiente partida se invierte el cargo y el abono para registrar las mercaderías traspasadas a la otra parte. Las partidas tercera y cuarta registran, a precio real y no al precio inflado de la transacción, un abono en la correspondiente cuenta de mercaderías por las mercaderías recibidas y un cargo en la correspondiente cuenta de mercaderías por las mercaderías enajenadas. En cada caso, la cuenta de trueque recoge el contrabalance del abono y del cargo, ya que al ser cantidades iguales, la cuenta queda saldada. Ympyn asegura que con este procedimiento siempre se sabe si uno pierde o gana con el trueque. Peele adopta este sistema en The pathe waye, siendo un préstamo directo de Ympyn. Muestra varios ejemplos que comienzan con los números 107-108, referentes a mercaderías entregadas o recibidas por trueque a precio excesivo. Las partidas están anotadas como en Ympyn, con la única diferencia de que las partidas tercera y cuarta no están registradas en el Diario sino que se pasan directamente (es posible que desde el Borrador) a las cuentas del Libro Mayor con el fin de -según Peele-, "to avoyde prolixitie". Al mismo tiempo, señala que:

21 Fra Luca Paciolo, opus cit., p. 134. 
... if you marke well, ye shall perceaue therby that thacco $(\mathrm{m})$ pte of barter is not onlye ballanced, but also the goodes receaued and deliuered at thexcessyue are uniformelie charged and discharged, as if they had bene bought and solde for readie monie.

$\mathrm{Ni}$ Ympyn ni Peele contemplan la posibilidad de que el mercader se dé cuenta de que ha obtenido beneficios porque en la operación de trueque la otra parte le ha pagado de más. Esta omisión sorprende, sobre todo, en Ympyn, pues insiste en que en las operaciones de trueque hay que ser muy astuto.

El Profesor Kats ha observado también otras correspondencias entre los tratados de Ympyn y Peele ${ }^{22}$. Así, se produce una indicación de cambio de fecha entre dos líneas del Libro Diario de The maner and fourme, siguiendo el modelo de Ympyn. Se considera que cualquier espacio en blanco en la parte inferior de la página del Diario es inútil; con el fin de evitar el añadido de partidas fraudulentas se traza un conjunto de barras oblicuas. Otra semejanza es la utilización de números romanos en las columnas del dinero del Libro Diario de The pathe waye, aunque esto no sucede en el primer tratado. Todas estas correspondencias nos llevan a concluir que entre 1553 y 1569 Peele estudió a fondo el tratado de Ympyn y reflejó esas ideas en su segundo libro.

\section{VI}

Sabemos que del libro de Hugh Oldcastle de 1543 no ha sobrevenido ninguna copia. Todo lo que conocemos de su contenido lo deducimos de la presunta reedición que John Mellis publicó en $1588^{23}$. En el prefacio Mellis dice que él es un mero

renuer and reuier of an auncient old copie printed here in London the 14. of August, 1543. Then collected, published, made and set forth by one Hugh Oldcastle Scholemaster, who as appeareth by his treatise then taught Arithmetike, and this booke in Saint Ollaues parish in Mark Lane.

22 P. Kats, "De invloed der Nederlanders de 16e en 17e eeuw op de Engelsche literatuur van jhet boekhouden", ed. cit.

23 Cfr. Juan Lanero Fernández, El esplendor de la teneduría de libros: la partida doble en los tratados contables ingleses de la dinastía Tudor (1543-1588), Universidad de León: Tesis Doctoral, 2004. 
Y en la última página del texto podemos leer:

Here endeth my Author, and for the better and plainer vnderstanding and practise of these rules, I haue hereunto added a little Inuentorie, lournal, and Leager, as followeth: with a briefe Treatise of Arithmetick all together. \& C.

Consecuentemente, el modelo de libros de cuentas es obra de Mellis; de lo que se deduce que el tratado de Oldcastle, como la exposición de Pacioli, carecían del mismo. Por lo tanto, no es sencillo determinar si Peele se vio influido por el tratado de Oldcastle. Una de las dificultades con la que nos encontramos es que buena parte del texto Oldcastle/Mellis es tan semejante al de Pacioli que existe fundamento para dudar si las correspondencias existentes entre Peele y Oldcastle/ Mellis se deben a una influencia directa o si, por el contrario, Peele las recibió de Pacioli o a través de Ympyn. Otra dificultad dura de salvar es que Mellis modificó el texto de Oldcastle en modo y lugares que no pueden precisarse con exactitud. Mellis informa a sus lectores de que en varios sitios ha procurado embellecer y aumentar la obra al dictado de sus modestos conocimientos. Así las cosas, cuando el texto de Oldcastle/Mellis se aparta de los de Pacioli, Manzoni o Ympyn, pero se corresponde con el de Peele, existe la incertidumbre de si éste se inspiró en el original de Oldcastle o si Mellis mejoró el texto con nuevas aportaciones tomadas de Peele. No obstante, todo indica que las novedades que se perciben en los tratados de Peele y Mellis son atribuibles al primero. Varios son los aspectos que cobran relevancia en esta interpretación. Como ya hemos señalado, los modelos de Mellis son suyos y no de Oldcastle; se puede deducir que para recopilar la información necesaria para esta parte de su libro, Mellis manejó la obra de Peele. A juicio del Profesor Kats, el material que Mellis nos presenta refleja la influencia directa de Peele ${ }^{24}$. Igualmente parece que Mellis se sirvió del tratado de Weddington. Por consiguiente, la parte de la exposición de teneduría de libros que Mellis añadió al original de Oldcastle dispone de numerosos préstamos provenientes de Peele y Weddington. Además, tenemos el detalle de que el título de la reedición del tratado de Oldcastle coincide con el de Weddington en sus veinticinco primeras palabras. 
Por otra parte, no debemos echar en saco roto el aspecto de que cuando Peele maneja los tratados de sus predecesores siempre introduce modificaciones propias. No obstante, algunos de los párrafos comunes en Peele y Mellis, que no son de origen pacioliano, son similares en palabras y estructuras en los tratados más notables del período. Sería sorprendente, pues, que Peele hubiera evitado el préstamo directo cuando se inspiró en todos los autores que influyeron en él salvo en el caso de Oldcastle. Esa correspondencia entre Peele y Mellis nos induce a pensar que el innovador fue el primero. Veámoslo en dos ejemplos. En The pathe waye Peele tiene un modelo de libros de cuentas para el negocio del propietario, en su calidad de mercader, separado de los libros de cuentas privados en los que figuran los intereses comerciales del propietario y otros asuntos financieros. El Inventario de apertura para el Libro Mayor del negocio sólo incluye dinero, deudas y mercaderías. Una vez que los acreedores se deducen de la suma de activos del negocio, "The remayne is the net substance, stocke or capitall, by thowner putt in trafique of marchandise".

Mellis en su capítulo III sigue a Pacioli en lo tocante a que, en el Inventario, no se asignan valores monetarios a cada uno de los activos no financieros. De este modo, no se adscriben valores monetarios a una serie de mercaderías, aunque sí se especifica que se deben anotar otros detalles, como: "Item I finde in grocerie wares thus many bales of ginger and so many cases of suger marked with such markes: Rehearsing euery sort by it selfe with his number signes and waight".

Los activos no financieros como los muebles y el ajuar de la casa están incluidos. Sin embargo, el capítulo concluye con las siguientes palabras:

The(n) gather together the whole summe of your ready money, debtes and goods, And therefrom Substract the totall summe of your Creditours, and the remaine is the net rest, substance or capitall of the owner to be put in a trafique, \& $c$.

Resulta evidente que Mellis insertó un párrafo indebido de Peele en la exposición pacioliana del tratamiento de Inventario de Oldcastle. Esta inserción resulta inequívoca, pues el término net rest que utiliza Mellis también aparece en Peele como sinónimo de capital o net substance. Pero Mellis también se sirve de The maner and fourme cuando se ocupa del Inventario. Éste, en el modelo de libros de cuentas, incluye activos personales y del negocio, cada uno de ellos con su valor monetario. El 
orden de los activos es el mismo que el de Peele y se aparta del de Pacioli que Mellis sigue en el capítulo III. Al adaptar su modelo de inventario al del primer tratado de Peele, Mellis olvidó modificar el enfoque paciliano de Oldcastle en el texto, con lo que la fraseología de éste y el ejemplo pedagógico difieren.

Todavía queda un segundo caso referente a los modelos de rayado de los libros de cuentas que se insertan en el texto. En The pathe waye el maestro explica a su discípulo "What bookes are nedefull \& the preparation of them", y le dice que no es preciso rayar ni el Inventario ni el Borrador: "Your Inuentorie or Memoriall shall not nede to be ruled but the maner of rulinge the Journall and Leager shall ensue, to saye". Acto seguido se abre un apartado, de dos páginas de extensión, con el siguiente encabezamiento:

This page cominge next, declareth how euerye leafe / and side in the Journall must be ruled, and the other two sides / followinge, declare howe everie face of accompte in the leager or greate booke (lyinge open) shallbe ruled, the one for the debitour / side, and the other for the creditour.

Después de las páginas rayadas, el discípulo dice que las ha estudiado con detenimiento y que ha entendido perfectamente a su maestro. El trazado de líneas se presenta poco a poco y en su debido lugar. Ejemplos similares de rayado y de índice del Libro Mayor, con una extensión de cuatro páginas, aparecen al final del capítulo XII de Mellis. El paso del texto al modelo es brusco. Además, a diferencia de Peele, los ejemplos aparecen varias páginas después de la que contiene la descripción del rayado. El propio capítulo XII se ocupa de un asunto distinto, como es el traspaso de partidas del Diario al Mayor, enfoque que claramente refleja el capítulo XIV de Pacioli.

Por todo lo que acabamos de ver, inferimos que el material de Mellis que no es pacioliano corresponde a préstamos que Mellis tomó de Peele. Esta deducción también es aplicable a la Norma de cargos y abonos del capítulo IX de Mellis que, exceptuando la ortografía, es la misma de The pathe waye de Peele: "All thinges receiued, or the receiuer must owe to all thinges deliuered, or to the deliuerer". Y lo mismo que en Peele, Mellis aconseja que la norma se aprenda "by rote, as by reason". En ambos libros la norma está impresa en caracteres romanos para destacarla de la impresión en letra gótica que la rodea. 
VII

En el capítulo $\mathrm{V}$ de The maner and fourme, Peele afirma que "You shall understande that euery one parcell in the Journall, ought to bee twoo in the Quaterne". Son palabras que tienen resonancia de Pacioli y de otros autores. Esta afirmación de Peele implica que cada partida del Diario indica una cuenta del Libro Mayor en la que hay que cargar y otra en la que hay que abonar. Las partidas simples del Diario de esta naturaleza podemos observarlas en Pacioli, Tagliente, Manzoni, Ympyn y en el primer tratado de Peele. No obstante, también se encuentran ejemplos de partidas compuestas del Diario en la práctica más temprana de la partida doble. Nos estamos refiriendo a una partida del Diario que debe cargarse o abonarse en más de una cuenta del Libro Mayor; ese sería el caso cuando las mercaderías se venden en parte en metálico y el resto a crédito. Pacioli conocía esta práctica. Así en su capítulo XI menciona una o varias cuentas en las que se debe cargar o abonar desde una partida del Diario. Manzoni sigue su ejemplo. Y, en el capítulo III de The maner and fourme, Peele también admite esta posibilidad cuando dice que habrá que poner una o varias cifras en la columna de referencia en el Libro Diario para el traspaso al Mayor (según el número de cuentas abiertas en éste) por encima o debajo de una "litle overthwart stroke". Es de suponer que las partidas compuestas del Diario no estaban incluidas en los modelos de los tratados porque cualquier transacción, por compleja que sea, se puede descomponer en un conjunto de partidas simples del Diario; y porque las partidas simples demuestran la naturaleza doble de las operaciones de forma más clara que las compuestas.

Nos encontramos con ejemplos de partidas compuestas del Diario en obras que no son de inspiración pacioliana como Ayn new Kunstlich Buech (1518) de Heinrich Schreiber ${ }^{25}$; Ein teutsch verstending Buchhalten (1531) (véase Figura 2) y Buchhalten, zwey künstliche und verstendige Buchhalten (1546) de Johann Gottlieb ${ }^{26}$; Practique briefve

25 Heinrich Schreiber, Ayn new Kunslich Buech welches gar gewiss und behend lernet nach der gemainen regel Detre, welschen practic.... Weytter ist hierinnen begissen Buechhalten durch das Zornal, Kaps und Schuldbuck... durch Henricu(n) Grammateum, oder Schreyber.... Nürnberg: Johannes Stuchs für Lucas Alantsee zu Wien, [1518].

26 Johann Gottlieb, Ein teutsch verstendig Buchhalten für Herren oder Geselschaffter inhalt wellischen process.... Darzu etlich Unterricht für die jugend un(d) andere, wie die Posten so ausz teglicher Handlung fliessen..., sollen im Jornal... eingeschrieben, und nach malsz zu Buch gepracht werden. [Nürnberg], F[riedrich] P[eypus], 1531; Buchhalten, zwey künstliche unnd verstendige Buchhalten..., Nürnberg: Joahn Petreius, 1546. 
pour cyfrer et tenir livres de compte (1550) de Valentin Mennher ${ }^{27}$. Weddington, a su vez, es el primer autor inglés que utiliza partidas compuestas en el Libro Diario. Igualmente, las encontramos en The pathe waye de Peele. $Y$, aunque el método de indicar en el Diario el traspaso a varias cuentas del Libro Mayor es diferente en los dos tratados, es bastante probable que Peele se viera influido por el que se había publicado dos años antes que el suyo. Peele incorpora el uso de partidas compuestas en su ejemplo 38. Expone el caso de un deudor al que se le concede un descuento si paga antes de la fecha acordada. Peele, en primer lugar, muestra dos ejemplos en el Diario, resultado de la descomposición de la transacción, en dos partidas simples. Acto seguido muestra dos partidas compuestas para el mismo tipo de operación e, igualmente, presenta las dos alternativas para otras transacciones. Utiliza el término Reperticion apperteyninge to sundrie accomptes, que representa las diversas cuentas que hay que cargar contra la cuenta que hay que abonar y detalla todas las cuentas relacionadas. Peele explica que con las partidas compuestas del Diario se economiza en partidas en el Libro Mayor,

... which order in some percelles will do greate ease, for happely a man maye bye or sell, at one instant many percelles of or to some one man, then by this order of repartinge, there needes but one somme in the margent of the Leager, for the creditour or debitour to aunswere a nomber of percelles eyther in debitour or creditour as the case requireth.

El término repartition o repertition, con la carga semántica de división o distribución, no se encuentra en la práctica más temprana en la que, por el contrario, sí hallamos los términos severals o sundries (gastos diversos).

Por otro lado, el uso de Libros Mayores secretos fue una práctica bien afianzada mucho antes de que se viera reflejado en la literatura contable. Así, en el tratado de Pacioli existen algunas consideraciones sobre la ocultación de información contable a los escribanos y a otros que tenían acceso a algunos libros contables, aunque no a todos. El franciscano italiano, en su capítulo $X$, afirma que las partidas del Inventario deberían asentarse en el Diario, pues este es -dice-, tu libro

27 Valentin Mennher de Kempten, Practique brifve pour cyfrer et tenir livres de compte touchant le principal train de marchandise, Antwerp: Jan Loe, 1550. 
secreto en el que el mercader podía registrar sus posesiones con todo detalle, incluidos los activos no financieros. Debemos recordar que en Pacioli las partidas del Libro de Inventario no están valoradas, salvo cuando su valor es la única unidad de medida, como dinero en efectivo o deudas y que, además del mercader, otros pueden asentar partidas en el Libro de Inventario. De este modo, el mercader que llevaba su propio Libro Diario podía ocultar a su personal la información relativa a sus activos privados y a su riqueza. En la misma línea se encuentra el capítulo IX de Mellis en el que el Libro Diario está definido como libro secreto y

Figura 2: Johann Gottlieb, Ein teutsch verstendig Buchhalten (1531)

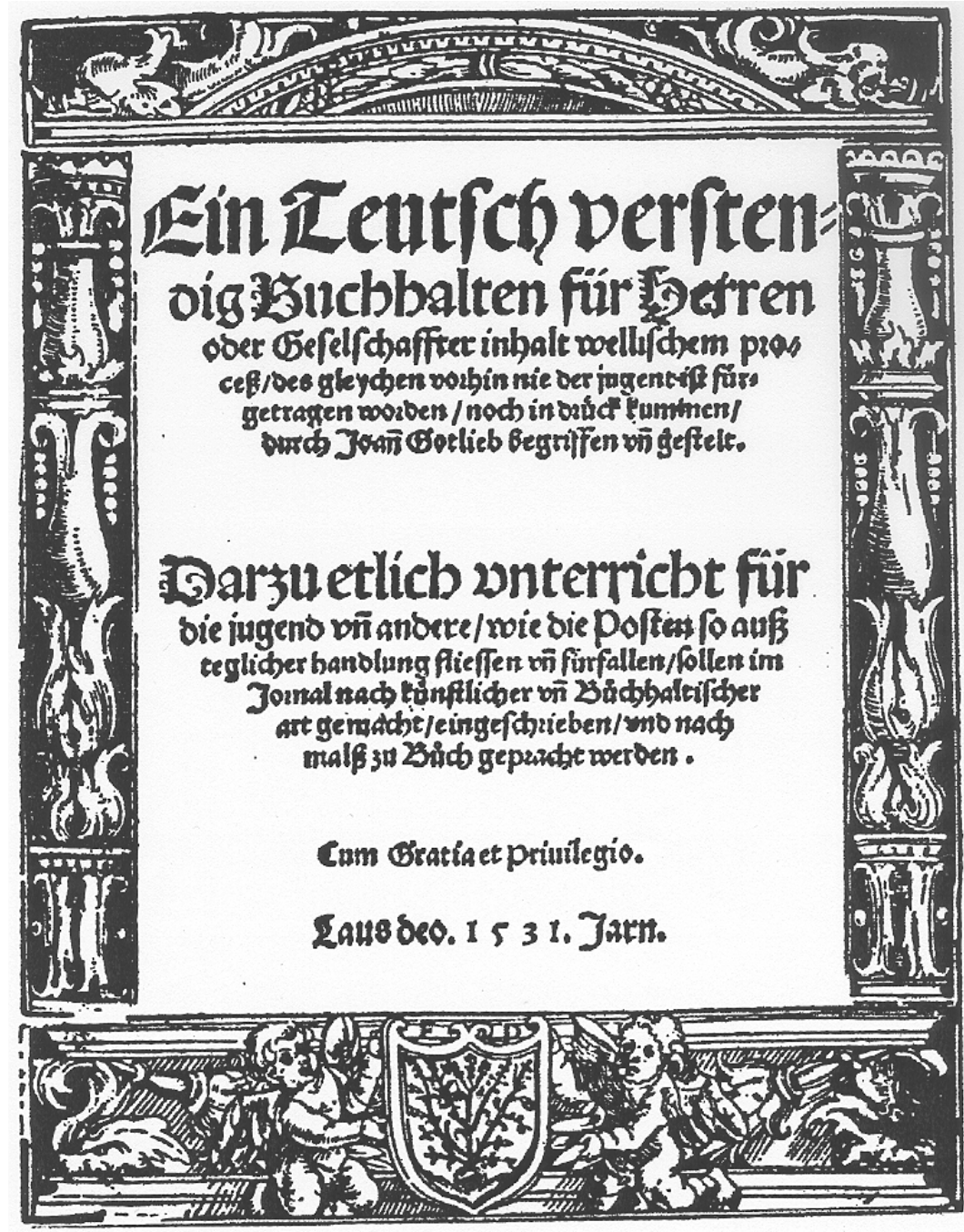


... therefore yee may therin shew write and expresse al your goods moueable and inmoueable, rehearsing euery parcel unto that leafe wherein it is sound, and also recorde thereof where it may bee founde, be it in chist, bore or bundell....

Mellis parece haber olvidado que en su capítulo III aconseja poner el valor de algunos activos no monetarios en el Inventario; además, en el modelo que propone, todos los artículos del Inventario figuran con su valor. Queda claro, pues, que Mellis fue inconsistente a la hora de modificar y aumentar el texto original de Oldcastle.

Ympyn, por su parte, aborda el tema de distinta manera. En su capítulo IV aconseja que las partidas del Libro de Inventario, que incluyen los valores de todos sus activos, no se anoten en el Borrador: "There are some that write in the beginnyng of this boke of Memoriall the Inventory, whiche I cannot praise, forasmuche as this boke commeth daily into the handes of every persone". El tratamiento del Diario no está claro. En su capítulo $X$ apunta que las partidas del Inventario deben traspasarse al Diario "reserving the boke of your Journall Inventory to be locked in a cheste, that it be not made comon and knowen to all suche as shall hande or write in your boke...". Por tanto, para Ympyn el Libro Diario no es un libro secreto. El secreto se garantiza segregando y separando las partidas del Inventario. No está clara la necesidad de registrar los detalles del Inventario en el Libro Diario, pues las partidas del Libro Mayor pueden hacerse directamente desde el Inventario. En cualquier caso, en su modelo de Libro Diario Ympyn considera las partidas de apertura del Inventario de igual modo que otras partidas que le siguen. No hay rastro de su segregación.

Peele, a su vez, aborda el tema en el capítulo XI de The maner and fourme: "What is to be done of suche as will haue their substaunce kepte in secrete, and of circumspect hede to be taken, that eche parcel of the Jornall be truly cast before it be borne into the quaterne". La solución es la misma que presenta Ympyn:

They maye binde their inuentorye and the parcels therof whiche are borne into the Jornall, in the formost ende of their quaterne before the kalender [índice], and beare the same parcels orderly bothe debitors \& creditors into the same quaterne.

Weddington fue el primero en describir la división del Libro Mayor en Libro Mayor secreto o privado, en el que el mercader anota sus 
activos (privados y comerciales) y un Libro Mayor del negocio; a lo que añade una explicación de cómo deben interrelacionarse. Para abreviar Weddington no da ejemplos; es una tarea que queda en manos de Peele que abunda sobre el uso de dos Libros Mayores interrelacionados en The pathe waye: de una parte estaría el "greate Booke (...) for thaccomptes in trafique of Merchaundies", que llevaría el sirviente; y de la otra, el "greate boke of accomptes contayninge my Priuate reconinge writton and kepte in the custodie of me...", que, como se indica, llevaría el propietario. Es evidente la superioridad y la elegancia contable, si se nos permite la expresión, de este método para preservar el secreto. No obstante, Peele también se refiere al método de segregar los detalles del Inventario de los libros de cuentas a los que tienen acceso personas que no son ni sus propietarios ni sus contables. En el modelo de cuentas para las operaciones mercantiles del propietario -trafique in marchaundise-, el Inventario se registra en un libro aparte:

... this Inuentorie beinge a booke of it selfe, must by thacco $(\mathrm{m})$ pte keper, be kept a parte, althoughe in this worke it be set before the iournall booke. And the reason is for that it maketh the stocke or capitall manifest, which is to be kepte secreate, excepte to the master and his acco(m)pte keper.

Los artículos del Inventario no se registran en el Libro Diario sino que se asientan directamente en el Libro Mayor, en realidad como abono único en la cuenta de capital, que es el excedente de activos sobre pasivos, es decir: el llamado net rest o stocke. Peele observa que una partida por cada artículo del inventario en la cuenta de capital "woulde haue required thrise asmuche tyme and labour at the least". además, ofrece una explicación referente a la colocación de la cuenta de capital en la primera hoja del Libro Mayor del negocio:

... the cause why, I haue begon with the stocke being the very latter parte of the Inuentorie, is for that 1 thinke it so meete, in consideratio(n) that it is his owne proper capitall, comitted to trafique in marchaundise, which being so placed in the first leafe, maye the better be kept secrete, for that it maye (if a man will) be sewed close with the former leafe, and but opened at the pleasure of the master or accompte keper.

Nos resta añadir que Peele no asimiló la innovación más importante de Weddington en la literatura de la teneduría de libros: la eliminación total del Diario y su sustitución por un conjunto de libros de 
anotación original dispuesto por la frecuencia de su uso: "... a memoriall, or wast Boke deuied into partis, or Bokes accordinge vnto thy dowingis, and a great Boke or lidger, to ballance and clere all manner of accomptis...".

Con todo, por lo que se refiere a la organización de los libros de cuentas, existen resonancias de Weddington en Peele. En efecto, Weddington aconseja que donde se produzcan muchas operaciones en metálico no se debe cargar o abonar en la cuenta de caja por cada uno de los conceptos sino que las partidas deben acumularse en un "boke of the pourse". Se entiende que los totales se pasan a diario de este libro a la cuenta de caja del Libro Mayor. Y advierte de que, en caso de no seguir este procedimiento, "...it wolde be verri difficult and tedious, and wolde consume your great Boke of marchandize to fast". En una argumentación ciertamente interesante, Peele explica que si un patrón necesita que uno de sus sirvientes se ocupe de las operaciones en metálico, este último puede llevar un libro de caja (chest booke). Hay dos maneras de tratar este asunto en el Libro Mayor del patrón. El primer método consistiría en que el patrón asiente todos los artículos del libro de caja en las cuentas correspondientes del Libro Mayor, incluida la cuenta de caja. En el segundo método, el patrón examina con detenimiento el libro de caja todos los días y asienta cada artículo directamente en las cuentas correspondientes del Libro Mayor, exceptuando la cuenta de caja. El patrón salda el libro del sirviente todas las semanas, pero no se asienta ninguna partida en la cuenta de caja del Libro Mayor del patrón hasta que no se cierre:

And thus from percell to percell, and from weke to weke, untill closynge up of the Masters booke, then this later order requireth to haue the last percell of monie founde remayning in the chest booke to be borne into the ballaunce of the Masters booker on the debitour syde, declaring from what leaffe in the chest booke the same is remoued althoughe by the first order it shall not neede to be borne in to the ballaunce at all, for it is done by order of thaccomptes it selfe, as by them that haue knowledge in these matters maye some be perciued.

Serían necesarios algunos ajustes más, pero no están especificados. El discípulo ha comprendido el primer método a la perfección: "Heare in is the Master eased of the payinge and receauinge the monie but not whit of the writinge". El segundo método, de enfoque similar al de Weddington, reduce la escritura. 
VIII

Como hemos visto, la excelencia es la cualidad que destaca en los dos tratados de Peele, en particular en The pathe waye. Peele supo recoger en sus libros las tendencias más innovadoras de la partida doble provenientes de los autores que le precedieron (véase Figura 3). Sin embargo su testigo no encontró el mismo relevo en las publicaciones contables posteriores. Está demostrado que Mellis manejó, aunque no siempre de forma apropiada, los tratados de Peele para su reedición de Oldcastle (1588). Y se puede decir lo mismo de John Carpenter para su tratado $A$ most excellent instruction for the exact and perfect keeping merchants bookes of accovnts, by vvay of debitor and creditor $(1632)^{28}$.

Richard Dafforne, a pesar de que ni en su exposición ni en su sistema de teneduría de libros se aprecian influencias de Peele, lo menciona en varias ocasiones en sus tratados. Así, en "The Epistle Dedicatory" de The Merchants Mirrour (1635) ${ }^{29}$ dice: "Want of love of this Art [la teneduría de libros], is the cause why James Peele, and others that have written in English upon this subject, are known by Name only, \& not by Imitation". Más adelante, en su "Introduction to Merchants Accompts", hace referencia al lema que preside la portada de The pathe waye: "Practice procureth perfection", y alaba a Peele por "[showing] us the fit ground-work how to conceal a mans Estate in the booking of his private accounts...". Y lamenta sus "well-entrances through neglecting age (or disdain of domestick writers, and extolling of foreign) are as strange to us, as though (as the saying is) they were written in Heathen Greek". En el

28 John Carpenter, A most excellent instruction for the exact and perfect keeping merchants bookes of accovnts, by vvay od debitor and creditor, after the Italian manner: most vsefull for all merchants, factors, and tradesman. Set forth in a most plaine and perfect manner, easie to be understood of the Learner, or Reader. And for the more explanation of all, here adioyned the practice by an Example of the Inventory, lournall and Lidger: with an ample Table to the whole worke. By I. C. Gent. London: Printed by I. B. for lames Boler, and are to be sold at the signe of the Marigold in Pauls Churchyard, 1632. Para un estudio de esta obra véase B. S. Yamey, "Early Books on Accounting. Carpenter's Most Excellent Instruction (1632) and Other Works", The Accountant, 137 (July to December, 1957), pp. 683-684.

29 Richard Dafforne, The Merchants Mirrour: or, Directions for the perfect ordering and keeping of his accounts; Framed by way of Debitor and Creditor, after the (so tearmed) Italianmanner: containing 250. Rare Questions, with their Answers, in forme of a Dialogue. As likewise, A Waste-book, with a compleat Journall, and Leager therunto appertaining; unto the which I have annexed two other Wastebooks for exercise of the Studious: and at the end of each is entred the briefe Contents of the Leagers Accounts, arising from thence. And also A Moneth-Book, very requisite for Merchants, and commodious for all other Science-Lovers of this famous Art. Compiled by Richard Dafforne of Northampton, Accountant and Teacher of the same, after an Exquisite Method, in the English, and Dutch Language. London: Printed by R. Young, for Nicolas Bourne, at the South-entrance of the Royal Exchange, 1635. 
tratado de Dafforne de 1535 también encontramos comentarios críticos, aunque respetuosos, sobre Peele $y$, en concreto, relacionados con el término repertition dentro del contexto de las partidas compuestas del Libro Diario:

The word REPERTITION is not used in my Booke, as James Peele, and many Merchants doe; which would much abridge the prolixity of my journall passages. True it is, I have not used that word Repertition, since Artdiscerning hath befriended mee. Concerning James Peele, I peaceably passe him, in respect of the Antiquity of his Worke, and long interned Body ("The Epistle Dedicatory").

Figura 3: Predecesores y sucesores de James Peele

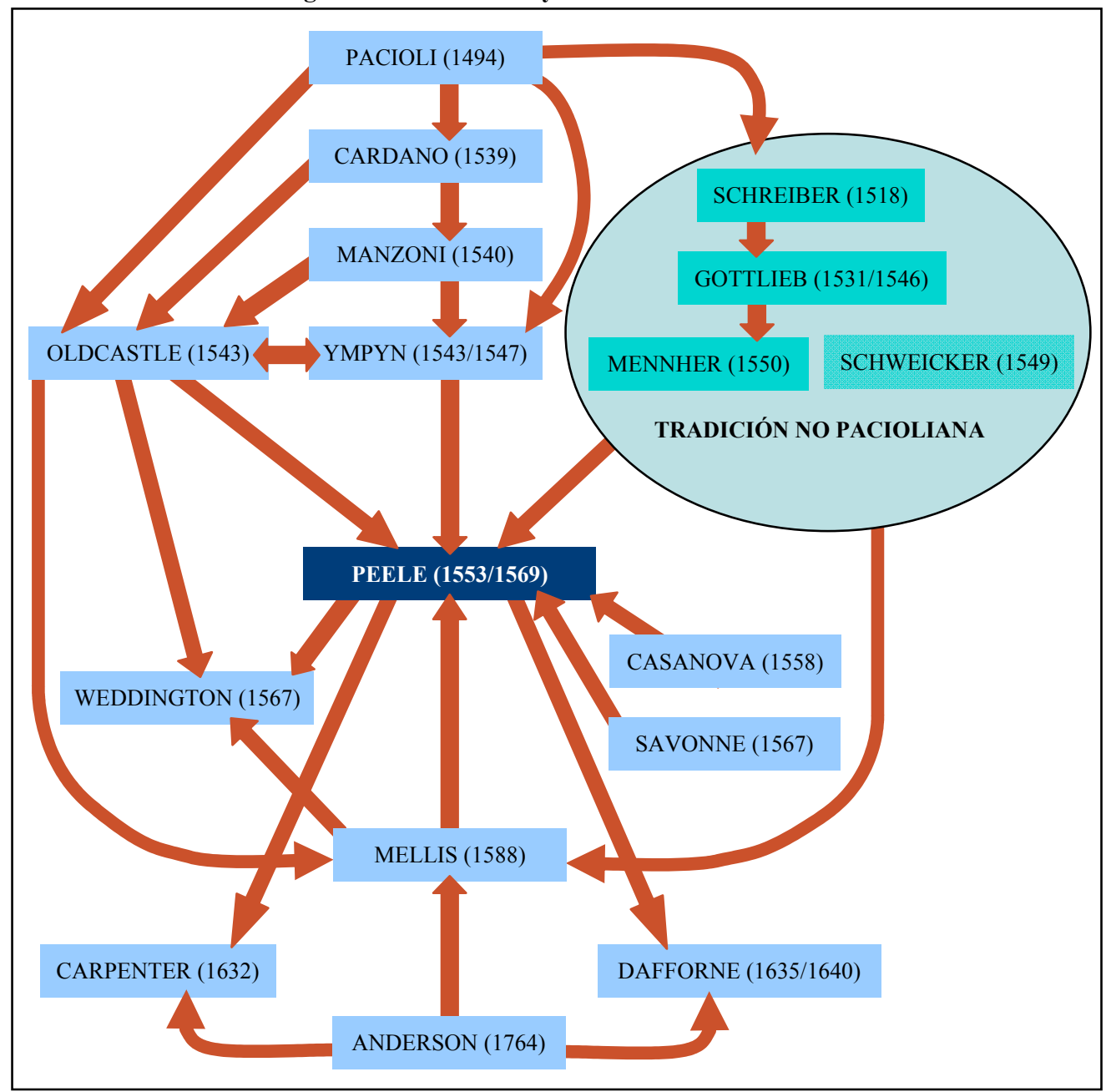

Fuente: Elaboración propia. 
Dafforne, en su tratado The apprentices time-entertainer accomptantly $(1640)^{30}$ hace referencia a la observación de Peele en lo tocante a la innecesaria apertura del Inventario cuando no se dispone de activos. Y hacia el final del libro señala: "But if this Art [teneduría de libros] be not well learned, and the matter heedfully carried, it will lead the Actor into a Labyrinth, as appeareth by James Peele his accompt straying Merchant".

Es ésta una clara alusión al diálogo entre el maestro de escuela y el mercader al comienzo de The pathe waye. No está de más recordar, por cierto, que Dafforne utiliza la forma del diálogo en una buena parte de su exposición. Dafforne menciona a Peele en su status de personaje histórico de una época ya pasada, no como autor de obligada referencia. La siguiente mención a Peele se demoró más de cien años en llegar; la encontramos en An Historical and Chronological Deduction of the Origin of Commerce (1764), una de las primeras historias del comercio, obra de A. Anderson

The Author has in his Possession the first Work ever published in England on the Art of Italian MerchantsAccounts or Book-Keeping by Double-Entry; it is a Folio, printed at London, Anno 1569, in a black Letter, the Author James Peele. The Stile is obsolete; (for Instance, on the Left-Hand Page of the Ledger, making A Dr. it is A oweth, and on the Right-Hand Page or Credit side, A is due to have) yet he has sufficiently testified, that he understood the true Grounds and Principles of Double Entry Accounts full as well as some who have written much later. In his Preface he says, "That many Merchants themselves were fond of learning of him, and of getting their Apprentices to be taught by him; and that although the Art be in a sort new in England, yet it had been long used by Merchants in foreign Parts"

30 Richard Dafforne, The apprentices time-entertainer accomptantly: or A Methodical means to obtain the Exquisite Art of Accomptantship: Digested int Three Parts, as is exemplified upon the next Leaf. By Richard Dafforne Author of the Merchants-Mirrour. Very requisite to be Exercised by all such as profess the Teaching of the said Art. Nowe Reviewed, and in several places Rectified (...) By John Dafforne..., The Third Edition. London: Printed by W. Godbid, for Robert Horne and are to be sold at his Shop at the South entrance of the Royal Exchange in Corn-hill, [1640], 1670.

31 Adam Anderson, An Historical and Chronological Deduction of the Origin of Commerce, from the Earliest Accounts to the present Time. Containing, an History of the Great Commercial Interest of the British Empire. To which is prefixed An Introduction, Exhibiting a View of the Ancient and Modern State of Europe; of the Importance of our colonies; and of the Commerce, Shipping, Manufactures, Fisheries, \& c. of Great Britain and Ireland: And their Influence on the Landed Interest. With An Appendix, Containing the Modern Politico-Commercial Geography of the several Countries of Europe, 2 vols. London: Printed for A. Millar, J. and R. Tonson, J. Rinngton, R. Baldwin, W. Johnston, L. Hawes, W. Clarke and R. Collins, T. Longman, J. Dodsley, and R. Horsfield. MDCCLXIV [1764], vol. I, p. 408. 
Y en verdad así fue: Pele comprendió los verdaderos principios de la partida doble; pero sus excelentes tratados se quedaron injustamente olvidados en la penumbra de los pretextos, la competencia de los contextos y casi ningún paratexto que los valorara en su justiprecio que fue, y sigue siendo, elevado.

\section{BIBLIOGRAFÍA}

ANDERSON, Adam (1764) An Historical and Chronological Deduction of the Origin of Commerce, from the Earliest Accounts to the present Time. Containing, an History of the Great Commercial Interest of the British Empire. To which is prefixed An Introduction, Exhibiting a View of the Ancient and Modern State of Europe; of the Importance of our colonies; and of the Commerce, Shipping, Manufactures, Fisheries, \& c. of Great Britain and Ireland: And their Influence on the Landed Interest. With An Appendix, Containing the Modern Politico-Commercial Geography of the several Countries of Europe, 2 vols. London: Printed for A. Millar, J. and R. Tonson, J. Rinngton, R. Baldwin, W. Johnston, L. Hawes, W. Clarke and R. Collins, T. Longman, J. Dodsley, and R. Horsfield. MDCCLXIV.

CARDANO, Girolamo Castiglione (1589) Practica Arithmetice, \& Mensurandi singularis. In qua que preter alias co(n)tinentur, versa pagina demonstrabit, Mediolani [Milán]: Annoa virgineo partu. M.D.XXXIX. Antonius Canellioneus Mediolani imprimebat impensis Bernardini Calusa.

CARPENTER, John (1632) A most excellent instruction for the exact and perfect keeping merchants bookes of accovnts, by vvay od debitor and creditor, after the Italian manner: most vsefull for all merchants, factors, and tradesman. Set forth in a most plaine and perfect manner, easie to be understood of the Learner, or Reader. And for the more explanation of all, here adioyned the practice by an Example of the Inventory, lournall and Lidger: with an ample Table to the whole worke. By I. C. Gent. London: Printed by I. B. for lames Boler.

CASANOUA, Aluise (1558) Specchio Lvcidissimo, nel quale si uedeno essere diffinito tutti i modi, \& ordini de scrittura, che si deue menare nelli negotiamenti della Mercantia, Cambii, Recambii, con li loro corrispondente, disgarbugliando, \& illuminando l'intelletto a negotianti. Opera non piv veduta, composta per Aluise Casanoua, Cittadin Venetiano, Anno Domini. M.D.LVIII. Con gratia et Privilegio dell'Illustrissimo Senato di Venetia per anni diece. 
CHRISTOFFELS, Jan Ympyn (1547) A notable and very excellente woorke, expressyng and declaryng the maner and forme how to kepe a boke of $a c c o(m) p t e s$ or reconynges, verie expedient and necessary to all Marchantes, Receiuers, Auditors, Notaries and all other. Translated with greate diligence out of the Italian toung into Dutche and out of Dutche, into French, and now out of Frenche into Englishe. London: Richard Grafton.

DAFFORNE, Richard (1635) The Merchants Mirrour: or, Directions for the perfect ordering and keeping of his accounts; Framed by way of Debitor and Creditor, after the (so tearmed) Italian-manner: containing 250. Rare Questions, with their Answers, in forme of a Dialogue. As likewise, A Waste-book, with a compleat Journall, and Leager therunto appertaining; unto the which I have annexed two other Wastebooks for exercise of the Studious: and at the end of each is entred the briefe Contents of the Leagers Accounts, arising from thence. And also A Moneth-Book, very requisite for Merchants, and commodious for all other Science-Lovers of this famous Art. Compiled by Richard Dafforne of Northampton, Accountant and Teacher of the same, after an Exquisite Method, in the English, and Dutch Language. London: Printed by R. Young.

- (1670) The apprentices time-entertainer accomptantly: or A Methodical means to obtain the Exquisite Art of Accomptantship: Digested int Three Parts, as is exemplified upon the next Leaf. By Richard Dafforne Author of the Merchants-Mirrour. Very requisite to be Exercised by all such as profess the Teaching of the said Art. Nowe Reviewed, and in several places Rectified (...) By John Dafforne..., The Third Edition. London: Printed by W. Godbid [1640].

GoTTLIEB, Johann (1531) Ein teutsch verstendig Buchhalten für Herren oder Geselschaffter inhalt wellischen process.... Darzu etlich Unterricht für die jugend un(d) andere, wie die Posten so ausz teglicher Handlung fliessen..., sollen im Jornal ... eingeschrieben, und nach malsz zu Buch gepracht werden. [Nürnberg], F[riedrich] P[eypus].

- (1546) Buchhalten, zwey künstliche unnd verstendige Buchhalten..., Nürnberg: Joahn Petreius.

KATS, P. (1925) "De invloed der Nederlanders de 16e en 17e eeuw op de Engelsche literatur van het boekhouden", Maandblad voor het boekhouden, 32.

- (1926) "Double-Entry Book-keeping in England before Hugh Oldcastle", The Accountant, 64, pp. 91-98.

- (1926) "Hugh Oldcastle and John Mellis-I", The Accountant, 64, pp. 483487. 
- (1926) "Hugh Oldcastle and John Mellis-II. The 'Briefe Instruction' by John Mellis", The Accountant, 64, pp. 641-648.

- (1930) "James Peele's 'Maner and Fourme,"' The Accountant, 82, pp. 41$44 ; 88-91 ; 119-122$.

LANERO, J.J. (2008) "Mercaderes ingleses de la época Tudor: Los libros de cuentas de Sir Thomas Gresham y John Smythe", Nuevos estudios sobre la historia de la contabilidad: orare et rationem reddere, Esteban Hernández Esteve y Begoña Prieto Moreno, coords., Diputación Provincial de Burgos, pp. 307-330.

LANERO FERnÁNDEZ, Juan (2004) El esplendor de la teneduría de libros: la partida doble en los tratados contables ingleses de la dinastía Tudor (1543-1588), Universidad de León: Tesis Doctoral.

MANZONI, Domenico (1540) Quaderno doppio col suo giornale, novamente composto, \& diligentissimamente ordinato, sicondo il costume di Venetia. Opera a ogni persona vtilissima, \& molto necessaria. Di Dominico Manzoni Opitergiense. Cvm gratia et privilegio del Illustrissimo Senato di Venetia, per Anni diece. MDXXXX.

MELLIS, John (1588) A briefe instruction and maner hovv to keepe bookes of Accompts after the order of Debitor and Creditor, as well as for proper Accompts partible \& c. By the three bookes named the Memoriall lournall \& Leager, and of other necessaries appertaining to a good and diligent marchant. The which of all other reckoninges is most lawdable: for this treatise well and sufficiently knowen, all other wayes and maners may be the easier \& sooner discerned, learned and knowen. Newly augmented and set forth by John Mellis Scholemaister, 1588. Imprinted at London by lohn Windet.

MENNHER DE KEMPTEN, Valentin (1550) Practique brifve pour cyfrer et tenir livres de compte touchant le principal train de marchandise, Antwerp: Jan Loe.

PACIOLO, Fra Luca (1878) Tractatus de Computis et Scripturis. Trattato de' Computi e delle Scritture, con Prefazione e Note, Edito per cura del Prof. Vincenzo Gitti, Torino: Tip. e Lit. Camilla e Bertolero.

PEELE, James (1553) The maner and fourme how to kepe a perfecte reconyng, after the order of the moste worthie and notable accompte, of Debitour and Creditour set foorthe in certain tables, with a declaration therunto belongyng, verie easie to be learned and also profitable, not only unto suche, that trade in the facte of Marchaundise, but also unto any other estate, that will learne the same. Imprinted at London, by Richard Grafton. 
- (1569) The pathe waye to perfectnes in th'accomptes of Debitour, and Creditour: in manner of a Dialogue, very pleasaunte and proffitable for Marchauntes and all oth' that minde to frequente the same: once agayne set forthe, and very much enlarged. By lames Peele Cittizen ans Salter of London, Clercke of Christes Hospitall, practizer and teacher of the same. Imprinted at London, in Paules Churchyarde. By Thomas Purfoote, dwellinge at the signe of the Lucrece. 16 August. Wisdome and Science Preuent Indigence. Practise procuereth perfection: la. Peele. 1566 (sic).

- (1979) The pathe waye to perfectnes, in th'accomptes of debitour and creditour, Eds. Osamu Kojima, B.S. Yamey, 2 vols., Kyoto: Daigakudo Books.

SAVONNE, Pierre (1567) Instrvction et maniere de tenir livres de raison ov de comptes par parties dovbles: Auec le moyen de dresser Carnet pour le virement \& rencontre des parties, qui se font aux foires es payements de Lyon, \& autres lieux: Livre necessaire a touvs marchans $\&$ autres personnes, qui s'entremectent d'aucunes affaires, ou negoces affectées a quelques conference ou rendition de comptes. Par Pierre Savonne, dict Talon, natif d'Auignon, Conté de Benisse A Paris. Au Compas d'Or, Rue Sainct lacques. M.D.LXVII.

SCHREIBER, Heinrich (1518) Ayn new Kunslich Buech welches gar gewiss und behend lernet nach der gemainen regel Detre, welschen practic.... Weytter ist hierinnen begissen Buechhalten durch das Zornal, Kaps und Schuldbuck ... durch Henricu(n) Grammateum, oder Schreyber.... Nürnberg: Johannes Stuchs für Lucas Alantsee zu Wien.

SCHWEICKER, Wolfgang (1549) Zwifach Buchhalten sampt seine(n) Giornal, des selben Beschlus, auch Rechnungzuthun \& c..... Nürnberg: Johan (n) Petreius.

VANES, Jean, ed. (1974) The Ledger of John Smythe, 1530-1550, from the Transcript Made by John Angus, London: Her Majesty's Stationery Office.

WEDDINGTON, John (1567) A breffe instruction, and manner howe to kepe, marchantes bokes of accomptes. After the order of Debitor and Creditor, as well for proper accomptes, partable, factory, and other, \& c. Verry nedefull to be knowen, and vsid of all men, in the feattis of marchandize. Novve of late nevvly, set forthe, and practisyd, By lohan Weddington Cyttizen of London. M.D.LXVII. The trewthe sekethe no corners. Prenttyd in Andvvarpe by Petter van Keerberghen.

YAMEY, B.S. (1957) "Early Books on Accounting. Carpenter's Most Excellent Instruction (1632) and Other Works", The Accountant, 137 (July to December), pp. 683-684. 